\title{
Understanding climate change policy and action in Portuguese municipalities: A survey
}

\author{
Inês Campos ${ }^{\mathrm{a}, *, 1}$, João Guerra ${ }^{\mathrm{b}, 2}$, José Ferreira Gomes ${ }^{\mathrm{b}, 2}$, Luísa Schmidt ${ }^{\mathrm{b}, 2}$, Filipe Alves ${ }^{\mathrm{a}, 1}$, \\ André Vizinho ${ }^{\mathrm{a}, 1}$, Gil Penha Lopes ${ }^{\mathrm{a}, 1}$ \\ a Centre for Ecology, Evolution and Environmental Changes (CE3C) University of Lisbon, Faculty of Sciences, Portugal \\ ${ }^{\mathrm{b}}$ University of Lisbon, Institute of Social Sciences, Portugal
}

\section{A R T I C L E I N F O}

\section{Article history:}

Received 23 June 2016

Received in revised form 4 November 2016

Accepted 10 December 2016

\section{Keywords:}

Climate change

Survey

Municipalities

\begin{abstract}
A B S T R A C T
Robust strategies and action-plans are essential in tackling climate change. Given the local and contextspecific nature of climate impacts, the involvement of municipalities is key for effective mitigation and adaptation solutions. Due to its vulnerability and low level of adaptive capacity, Portugal offers insights into adaptation research and practice in Europe. This article hypothesizes that National and European climate change adaptation strategies are not effectively involving municipalities, and are thus losing out on the opportunity to take stock of local responses for climate change mitigation and adaptation. To address this issue, a survey by questionnaire was done to Portuguese municipalities, and data was collected regarding the following: the importance attributed to climate change; the mitigation and adaptation measures planned and implemented; the main drivers, concerns, and triggers promoting climate policy and actions; and access to information and knowledge. 109 valid responses were collected across the country from a universe of 308 municipalities. Results show climate change in planning agendas is still 'little' or 'not important'. There is also a clear difference in the drivers and concerns motivating climate policy, and action between Littoral and Inland regions. Overall, there is a greater focus on mitigation than adaptation. The discussion highlights the need for capacity building, the issue of equity, the role of European networks, and the relevance of cultural differences between Littoral and Inland regions. The conclusion distils the main lessons learned concerning these challenges and needs, the role of transnational networks, and the cultural contexts for building resilience, through adaptation, across Europe.
\end{abstract}

(c) 2016 Elsevier Ltd. All rights reserved.

\section{Introduction}

There is little doubt the world readily needs ambitious climate change mitigation and adaptation plans of action. As reported by the Organisation for Economic Co-operation and Development (OECD, 2015) the combined effect of climate change impacts on global annual GDP is projected to be between $1.0 \%$ up to $3.3 \%$, until 2060 (based on a likely rise in global temperature of $1.5^{\circ} \mathrm{C}$ to $4.5^{\circ} \mathrm{C}$; OECD, 2015). Climate induced damages from extreme events (e.g. hurricanes), as well as damages incurred due to energy and tourism,

\footnotetext{
* Corresponding author.

E-mail addresses: isobralcampos@gmail.com (I. Campos), joao.guerra@campus.ul.pt (J. Guerra), jose.ferreira@ics.ul.pt (J.F. Gomes), mlschmidt@ics.ulisboa.pt (L. Schmidt), fmalves@fc.ul.pt (F. Alves), afvizinho@fc.ul.pt (A. Vizinho), gppenha-lopes@fc.ul.pt (G.P. Lopes).

1 Faculdade de Ciências, Universidade de Lisboa, 1749-016 Lisboa, Portugal.

2 Avenida Professor Aníbal Bettencourt 9, 1600-189 Lisbon, Portugal.
}

are expected to have a significant impact on a local scale $(O E C D$, 2015, p. 14). Such evidence suggests there are strong incentives for mitigation and adaptation actions on multi-scale; global, regional and local governance levels (Hallegatte et al., 2011).

Acting in response to climate change is 'about adjusting to risks, either in reaction to or in anticipation of changes arising from changing weather and climate' (Adger et al., 2012: 112). Mitigation refers to the reduction of global greenhouse gas emissions over the coming decades, and adaptation refers to the ability of human and ecological systems to respond to the impacts and effects of climate change (Parry et al., 2007).

In Europe, several countries developed National Adaptation Strategies, yet only a few reached an implementation stage. There is a need to learn more about policies and actions being developed at a local level, and how those experiences can be shared and/or supported at the country and European levels (Hunt and Watkiss, 2011). The latest reports from the European Environmental Agency (EEA) found that it is a challenge for countries to involve municipal- 
ities in national adaptation policies, and highlight the importance of sharing experiences and lessons learned across levels of governance (EEA, 2014, 2015). Portugal is highly vulnerable to climate change impacts (from rising sea levels, to heat waves, flooding and droughts), with a low level of adaptive capacity, with very few implemented measures, and little policy integration and coordination across levels and scales of governance (O'Riordan et al., 2014; Carvalho et al., 2014; Ciscar et al., 2011). The requirement for implementing climate change policies is, in the majority of cases, voluntary and non-binding (Carvalho et al., 2014). This article hypothesizes that National and European climate change adaptation strategies are not effectively involving municipalities, and are thus losing out on the opportunity to take stock of the growing importance of local responses for climate change mitigation and adaptation.

To address its hypothesis, this research article draws from the Portuguese case and surveys municipal mitigation and adaptation strategies and action-plans being developed. Particular attention is given to the main drivers and triggers leading local responses, as well as the key concerns and institutional capacity (i.e. existent organisational structures, access to information and knowledge, and participation in European networks). Still at the dawn of its climate policies, the Portuguese case should add to a better understanding of local level adaptation processes, and provide insights regarding the synergies between municipal policy-making, National and European strategies, and the role of transnational networks (Bulkeley, 2010; Amundsen et al., 2010).

Learning more about municipal action can be a step towards promoting more adapted societies and more equitable solutions for climate change. Research has identified some determinants for incrementing adaptive capacity (Brooks et al., 2005). Social capital is an important factor (Adger, 2003; Pelling and High, 2005), which refers to immaterial assets and resources incrementally developed by individuals and groups, and reproduced through networking and learning frameworks (Kay, 2006). Social capital studies highlight that the different determinants or capacities of a society to act in response to climate change are strengthened by a collective action, building upon networks of organizations, institutions and social groups (Adger, 2003). Then, societies characterized by higher levels of social capital tend to achieve superior performance at national and local governance levels (Putnam, 2000). Collective action should both lead and result from higher levels of policy integration (the integration of climate change policies in various sectorial and multi-level policies) (Lenschow, 2002), and mainstreaming (how climate change enters diverse political and civil society discourses) (Smit and Wandel, 2006). Sharing knowledge and the lessons learned are equally central for mainstreaming (Cash et al., 2006).

Climate change impacts and the range of possible solutions are framed by spatial and temporal boundaries and are also a context-specific processes (Smit and Wandel, 2006); often more resource-dependent communities will be affected by change (Adger et al., 2006). Therefore, equity is a key issue (Pelling and High, 2005). Regardless of who is making decisions, every climate change policy is likely to have its losers and winners (Agarwal et al., 2012; Pelling et al., 2014). The more stakeholder' groups, organisations and institutions are included in the decision-making process, the more likely the solutions are to be effective and fair, and aid in preventing the exclusion of vulnerable and marginalised groups (Olsson et al., 2006). Governance frameworks should allow the integration of shared goals by a wide variety of social actors, from scientists, to decision-makers and practitioners (Füssel, 2007; Amaru and Chhetri, 2013). Yet, as in most European countries, the coordination of climate change policies in Portugal has traditionally been done by ministries and government agencies, with scarce involvement of other stakeholders (O'Riordan et al., 2014), leaving little space for the build-up of social capital, and effective and fair strategies in the long-term.

Promoting well-adapted societies (Folke et al., 2010) also refers to a capacity for "renewal, re-organization and development" (Folke, 2006: 253). Well prepared organizational structures have been found to be important for encouraging adaptability (Folke et al., 2005; Lebel et al., 2006). Literature on adaptive co-management (Olsson et al., 2006; Armitage et al., 2008), emphasizes the importance of robust institutions as key determinants for building adaptive capacity. Strong institutions are thought to contribute to a higher level of policy integration, coordination and mainstreaming, while also leading to more integrated solutions in climate change (Folke et al., 2005). Guided by these notions, the survey sought to learn more about the current institutional capacity of municipalities.

The cultural dimension of climate change is an increasingly relevant subject, although it has not yet been appropriately explored in quantitative studies, it has been argued that culture mediates societal responses to climate change (Adger et al., 2012). The understanding of culture is strongly linked to physical spaces (Knez, 2005; Adger et al., 2012). This study hopes to also investigate how climate adaptation is perceived, taking into account possible spatial-cultural differences between coastal and inland regions. Such knowledge should be relevant for researchers, practitioners and policymakers in Portugal and across Europe.

Informed by these insights, the paper continues by describing the quantitative method implemented. The results section will provide the main findings concerning the current state of mitigation and adaptation policy, and actions in the country. The discussion focuses on analysing the specific dynamics of climate policies at the local level, taking into account the issues raised in this introduction. The conclusion distils the main lessons learned for Portugal and other European countries.

\section{Methodology}

The article results from a first national survey by questionnaire to Portuguese municipalities on the topic of climate change. The aim was to acquire a baseline knowledge on local policy strategies and actions regarding mitigation and adaptation strategies. Data should also investigate how climate adaptation is perceived, taking into account possible spatial-cultural differences between coastal and inland regions. 109 valid responses were collected through a questionnaire, corresponding to $35.4 \%$ of Portuguese municipalities, sent to all 308 municipalities.

A stratification method was used to ensure a proportional representation of the sample (Waksberg, 1978). The most adequate variables for the representativeness of the sample were identified, drawing from statistical data from the National Statistics Institute (INE, 2011). The first primary variable was "NUTS II", which is the Nomenclature of Territorial Units for Statistics (NUTS), developed by the Eurostat and used for statistical purposes in Portugal. NUTS II comprises the following regions: North, Centre, Lisbon, Alentejo, Algarve, Azores and Madeira. The other primary variables used were the Habitat of the municipality (i.e. Number of inhabitants), and the leading political party (in 2014/2015). A relative weight (\%) was determined for each variable in order to form categories of municipalities, within the universe of 308 municipalities. To ensure the same probability in the selection of municipalities, and to choose (in the same proportion) the municipalities that integrated the final sample, a random sampling procedure was used for each of the sample categories. Table 1 shows the sample according to the three main selection variables.

To collect responses, an online survey by questionnaire was implemented, and reinforced through numerous rounds of contact 
Table 1

Sample of respondents from Portuguese municipalities, according to Region Nuts II; to Leading political party and Habitat (number of inhabitants).

\begin{tabular}{|c|c|c|c|c|c|c|c|c|}
\hline Region NUTS II & Sample & Universe & Political party of the Mayor & Sample & Universe & Habitat (number of inhabitants) & Sample & Universe \\
\hline North & $25.6 \%$ & $27.9 \%$ & Socialist Party & $47.7 \%$ & $48.7 \%$ & $<7500$ & $22 . \%$ & $29.5 \%$ \\
\hline Centre & $33.9 \%$ & $32.4 \%$ & Social democratic party & $25.6 \%$ & $27.9 \%$ & $7500-20,000$ & $22.9 \%$ & $29.2 \%$ \\
\hline Lisbon & $6.4 \%$ & $5.8 \%$ & PCP-PEV(CDU) & $13.7 \%$ & $11 \%$ & $20,000-50,000$ & $29.3 \%$ & $22 . \%$ \\
\hline Alentejo & $19.2 \%$ & $18.8 \%$ & CDS-PP & $1.8 \%$ & $1.6 \%$ & $50,000-100,000$ & $14.6 \%$ & $11.3 \%$ \\
\hline Algarve & $5.5 \%$ & $5.1 \%$ & PSD/CDS/Others & $8.2 \%$ & $6.4 \%$ & $>100,000$ & $11 \%$ & $7.7 \%$ \\
\hline Azores & $6.4 \%$ & $6.1 \%$ & Independent & $3 \%$ & $4 \%$ & - & - & - \\
\hline Madeira & $2.7 \%$ & $3.5 \%$ & - & - & - & - & - & - \\
\hline
\end{tabular}

via telephone with Mayor Offices, ensuring a systematic support and follow up of the data collection process. Contacts with municipalities increased in proportion to the differences between the sample and the universe, within the different created categories (according to the selection variables). More contacts occurred with municipalities, that fitted the categories where data was missing, until a representative sample was achieved, which represented $35.4 \%$ of the total universe and provided a high level of confidence in the results. The relative weight of the seven regions, of the six groups created based on the number of inhabitants, and the five political parties leading Portuguese municipalities at the time (2015), is maintained both in the sample and the universe.

Throughout the survey, two analytical variables were taken equally into account: participation in European networks (e.g. the Covenant of Mayors) and the municipality's location (Littoral versus Inland). These two variables were included in order to draw some insight into the role of transnational networks, and to explore possible variances between policy responses of coastal and inland regions that could be rooted in spatial-cultural differences. Accounting for the role of networks could draw some light into the potential for collective action through the build-up of networks across Europe. $35.8 \%$ of respondents were signatories of the Covenant of Mayors, while in the universe of Portuguese municipalities the percentage was $34.41 \%$. Similarly, $23.9 \%$ of responses were from municipalities located in Littoral regions, which was a higher percentage than the representative universe of $16.2 \%$.

Due to the nature of the survey by questionnaire method, which presupposes an inflexible formulation and sequence of questions, there were some limitations to the responses, for the most part circumscribed to foreseen hypotheses. Therefore, the survey was complemented by a collection of documental and statistical data from official statistics, as well as, by insights learned in the context of qualitative case study research (e.g. the Cascais municipality, see Campos et al., 2016a). Excluding a first introductory section with the goal of characterizing the municipality and respondents (i.e. name, region, number of inhabitants, political party), the questionnaire had four sections focussing on:

(1) the importance of climate change mitigation and adaptation; existent organisational structures to support climate policy planning;

(2) climate policy and actions being planned and implemented in Portuguese municipalities;

(3) drivers, concerns and triggers for policy and action, and

(4) knowledge and information on climate change.

Data on the profile of respondents was important to ensure respondents would be able to adequately reply to questions pertaining to local municipal policies and activities. Respondents were either spatial planners or policymakers. Planners held significant technical and expert knowledge and were leading relevant departments or workgroups related to environmental and climate change policies. Policymakers held decision-making powers and coordinated activities within the municipality. In the majority of the cases (71.5\%), the spatial planners responded to the survey, the remain- ing (28.4\%). were answered by policymakers. Regarding planners, $28.4 \%$ claimed they were high level officers from other areas (not environmental), $22 \%$ were high level officers within the scope of environmental policies and $21.1 \%$ were head of environmental departments. Policymakers were for the most part (18.3\%) heads of environmental policy, $0.9 \%$ were heads of other departments, and $9.2 \%$ were Mayors of the municipality. The strategy of contacting by phone each municipality ensured that those responding were well informed on the survey's topic.

\section{Results}

The results provide a first diagnosis of climate change policy planning and implementation in Portuguese municipalities. Respondents were surveyed on: the importance of climate change adaptation policies in municipal planning agendas, the institutional capacity to develop climate change policies (e.g. existence of a municipal department), the type of response being developed or implemented, relevant policy instruments (e.g. European strategy), actions being implemented (including the sectorial focus, the drivers, concerns and triggers motivating the adoption of climate change policies), and the sources and type of information and knowledge on climate change.

\subsection{Climate change in municipal planning agendas}

The majority of the municipalities declared that climate change is not a key issue in local policy agendas. $56.9 \%$ of national responses were situated in the lower first three categories of the scale. The importance attributed to climate change adaptation is not equally distributed in the territory, nor is it in relation to the habitat of the municipality. Regions, with a higher number of inhabitants (i.e. Centre; Lisbon; Madeira Islands, the Algarve) attributed more importance than those with a lower number of inhabitants (see Table 2). Values vary equally in relation to the municipalities' participation in European networks. Signatories of the Covenant of Mayors (CM) attributed importance to climate change policies (see Table 2).

Regarding institutional capacity, the survey highlights a lack of appropriate internal organic structures (e.g. a specific department) within municipalities, since $97.2 \%$ of municipalities did not have a specific department to handle climate change responses. $15.7 \%$ claimed there is a department, which accumulates other functions, and 52.8\% referred there was only an environmental department. The $2.8 \%$ with a special department are located in the Centre Region, where municipalities have a high number of inhabitants. Significant differences are noted between signatories and non-signatories of the European networks (see Table 2).

Respondents were asked if mitigation and adaptation actions, or both, were being developed by the municipality. 50.5\% responded they were developing actions, $43.1 \%$ claimed there was no action, and $6.5 \%$ claimed that they were not aware if actions were or were not being developed. Regarding the type of action (i.e. mitigation, adaptation, or both), differences are noted between signatories and 
Table 2

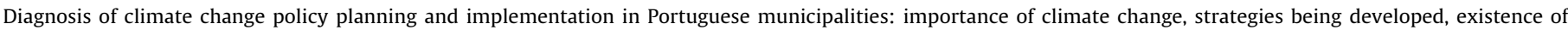

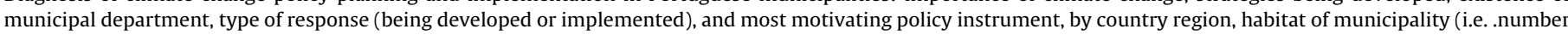
of inhabitants), and participation in European Networks (i.e. signatories of Covenant of Mayors/Mayors Adapt versus non-signatories).

\begin{tabular}{|c|c|c|c|c|c|c|c|}
\hline Country Region & North & Centre & Lisbon & Alentejo & Algarve & Azores & Madeira \\
\hline No importance 1 & $22.2 \%$ & $0 \%$ & $0 \%$ & $66.7 \%$ & $0 \%$ & $11.1 \%$ & $0 \%$ \\
\hline 2 & $31 \%$ & $24.1 \%$ & $10.3 \%$ & $17.2 \%$ & $6.9 \%$ & $10.3 \%$ & $0 \%$ \\
\hline 3 & $20.8 \%$ & $33.3 \%$ & $0 \%$ & $25 \%$ & $4.2 \%$ & $12.5 \%$ & $4.2 \%$ \\
\hline 4 & $38.1 \%$ & $42.9 \%$ & $0 \%$ & $9.5 \%$ & $9.5 \%$ & $0 \%$ & $0 \%$ \\
\hline 5 & $17.6 \%$ & $52.9 \%$ & $11.8 \%$ & $11.8 \%$ & $0 \%$ & $0 \%$ & $5.9 \%$ \\
\hline Very important 6 & $11.1 \%$ & $44.4 \%$ & $22.2 \%$ & $0 \%$ & $11.1 \%$ & $0 \%$ & $11.1 \%$ \\
\hline
\end{tabular}

$\mathrm{x}^{2}(30)=44.967, p<0.05$

Is climate change adaptation an important orientation of public policy planning in your municipality?

\begin{tabular}{|c|c|c|c|c|c|}
\hline Habitat of Municipality & $<7.500 \mathrm{M}$ & $7.500 \mathrm{M}-20 \mathrm{M}$ & $20 \mathrm{M}-50 \mathrm{M}$ & $50 \mathrm{M}-100 \mathrm{M}$ & $>100 \mathrm{M}$ \\
\hline No importance 1 & $11.1 \%$ & $11.1 \%$ & $44.4 \%$ & $33.3 \%$ & $0 \%$ \\
\hline 2 & $20.7 \%$ & $13.8 \%$ & $41.4 \%$ & $6.9 \%$ & $17.2 \%$ \\
\hline 3 & $33.3 \%$ & $41.7 \%$ & $20.8 \%$ & $4.2 \%$ & $0 \%$ \\
\hline 4 & $33.3 \%$ & $23.8 \%$ & $23.8 \%$ & $14.3 \%$ & $4.8 \%$ \\
\hline 5 & $11.8 \%$ & $23.5 \%$ & $23.5 \%$ & $11.8 \%$ & $29.4 \%$ \\
\hline $\begin{array}{l}\text { Very important } 6 \\
x^{2}(20)=41.159, p<0.01\end{array}$ & $0 \%$ & $11.1 \%$ & $22.2 \%$ & $55.6 \%$ & $11.1 \%$ \\
\hline
\end{tabular}

Is climate change adaptation an important orientation of public policy planning in your municipality?

\begin{tabular}{|c|c|c|}
\hline Covenant of Mayors/Mayors Adapt & Signatories & Non-Signatories \\
\hline No importance 1 & $22.2 \%$ & $77.8 \%$ \\
\hline 2 & $17.2 \%$ & $82.8 \%$ \\
\hline 3 & $29.2 \%$ & $70.8 \%$ \\
\hline 4 & $38.1 \%$ & $61.9 \%$ \\
\hline 5 & $52.9 \%$ & $47.1 \%$ \\
\hline Very important 6 & $77.8 \%$ & $22.2 \%$ \\
\hline
\end{tabular}

Is a Climate Change Adaptation Plan/Strategy being developed?

\begin{tabular}{|c|c|c|c|c|c|c|c|}
\hline Country Region & North & Centre & Lisbon & Alentejo & Algarve & Azores & Madeira \\
\hline No, no plan exists & $27.3 \%$ & $26 \%$ & $5.2 \%$ & $22.1 \%$ & $7.8 \%$ & $7.8 \%$ & $3.9 \%$ \\
\hline A plan is being developed & $11.8 \%$ & $70.6 \%$ & $0 \%$ & $11.8 \%$ & $0 \%$ & $5.9 \%$ & $0 \%$ \\
\hline A plan is being implemented & $45.5 \%$ & $27.3 \%$ & $9.1 \%$ & $18.2 \%$ & $0 \%$ & $0 \%$ & $0 \%$ \\
\hline Measures integrated in other plans & $0 \%$ & $50 \%$ & $50.0 \%$ & $0.0 \%$ & $0 \%$ & $0 \%$ & $0 \%$ \\
\hline
\end{tabular}

$\mathrm{x}^{2}(18)=32.421, p<0.05$

Is a Climate Change Adaptation Plan/Strategy being developed?

\begin{tabular}{|c|c|c|c|c|c|}
\hline Habitat of Municipality & $<7.500 \mathrm{M}$ & $7.500 \mathrm{M}-20 \mathrm{M}$ & $20 \mathrm{M}-50 \mathrm{M}$ & $50 \mathrm{M}-100 \mathrm{M}$ & $>100 \mathrm{M}$ \\
\hline No, no plan exists & $28.6 \%$ & $18.2 \%$ & $28.6 \%$ & $15.6 \%$ & $9.1 \%$ \\
\hline A plan is being developed & $5.9 \%$ & $23.5 \%$ & $47.1 \%$ & $17.6 \%$ & $5.9 \%$ \\
\hline A plan is being implemented & $9.1 \%$ & $45.5 \%$ & $18.2 \%$ & $0 \%$ & $27.3 \%$ \\
\hline Measures integrated in other plans & $0 \%$ & $50 \%$ & $0 \%$ & $25 \%$ & $25 \%$ \\
\hline
\end{tabular}

$\mathrm{n} / \mathrm{s}$

Is a Climate Change Adaptation Plan/Strategy being developed?

\begin{tabular}{|c|c|c|}
\hline Covenant of Mayors/Mayors Adapt & Signatories & Non-Signatories \\
\hline No, no plan exists & $27.3 \%$ & $72.7 \%$ \\
\hline A plan is being developed & $47.1 \%$ & $52.9 \%$ \\
\hline A plan is being implemented & $72.7 \%$ & $27.3 \%$ \\
\hline Measures integrated in other plans & $25 \%$ & $75 \%$ \\
\hline
\end{tabular}

$x^{2}(3)=10.183, p<0.05$

Is there a department responsible for implementing climate change mitigation and/or adaptation actions?

\begin{tabular}{|c|c|c|c|c|c|c|c|}
\hline Country Region & North & Centre & Lisbon & Alentejo & Algarve & Azores & Madeira \\
\hline Yes, there is an inter-department committee for CC & $0 \%$ & $100 \%$ & $0 \%$ & $0 \%$ & $0 \%$ & $0 \%$ & $0 \%$ \\
\hline Yes, there is a specific department for CC & $100 \%$ & $0 \%$ & $0 \%$ & $0 \%$ & $0 \%$ & $0 \%$ & $0 \%$ \\
\hline Yes, there is a department, which accumulates other functions & $29.4 \%$ & $41.2 \%$ & $17.6 \%$ & $5.9 \%$ & $0 \%$ & $0 \%$ & $5.9 \%$ \\
\hline No, but there is an environmental department & $21.1 \%$ & $35.1 \%$ & $5.3 \%$ & $21.1 \%$ & $8.8 \%$ & $7 \%$ & $1.8 \%$ \\
\hline No, there is not & $32.3 \%$ & $25.8 \%$ & $0 \%$ & $25.8 \%$ & $3.2 \%$ & $9.7 \%$ & $3.2 \%$ \\
\hline
\end{tabular}

No, there is not

$\mathrm{n} / \mathrm{s}$ 
Table 2 (Continued)

\begin{tabular}{|c|c|c|c|c|c|}
\hline Habitat of Municipality & $<7.500 \mathrm{M}$ & $7.500 \mathrm{M}-20 \mathrm{M}$ & $20 \mathrm{M}-50 \mathrm{M}$ & $50 \mathrm{M}-100 \mathrm{M}$ & $>100 \mathrm{M}$ \\
\hline Yes, there is an inter-department committee for CC & $0 \%$ & $0 \%$ & $50 \%$ & $50 \%$ & $0 \%$ \\
\hline Yes, there is a specific department for CC & $0 \%$ & $100.0 \%$ & $0 \%$ & $0 \%$ & $0 \%$ \\
\hline Yes, there is a department, which accumulates other functions & $11.8 \%$ & $23.5 \%$ & $35.3 \%$ & $11.8 \%$ & $17.6 \%$ \\
\hline No, but there is an environmental department & $19.3 \%$ & $28.1 \%$ & $28.1 \%$ & $12.3 \%$ & $12.3 \%$ \\
\hline No, there is not & $35.5 \%$ & $12.9 \%$ & $29.0 \%$ & $19.4 \%$ & $3.2 \%$ \\
\hline
\end{tabular}

$\mathrm{n} / \mathrm{s}$

Is there a department responsible for implementing climate change mitigation and/or adaptation actions?

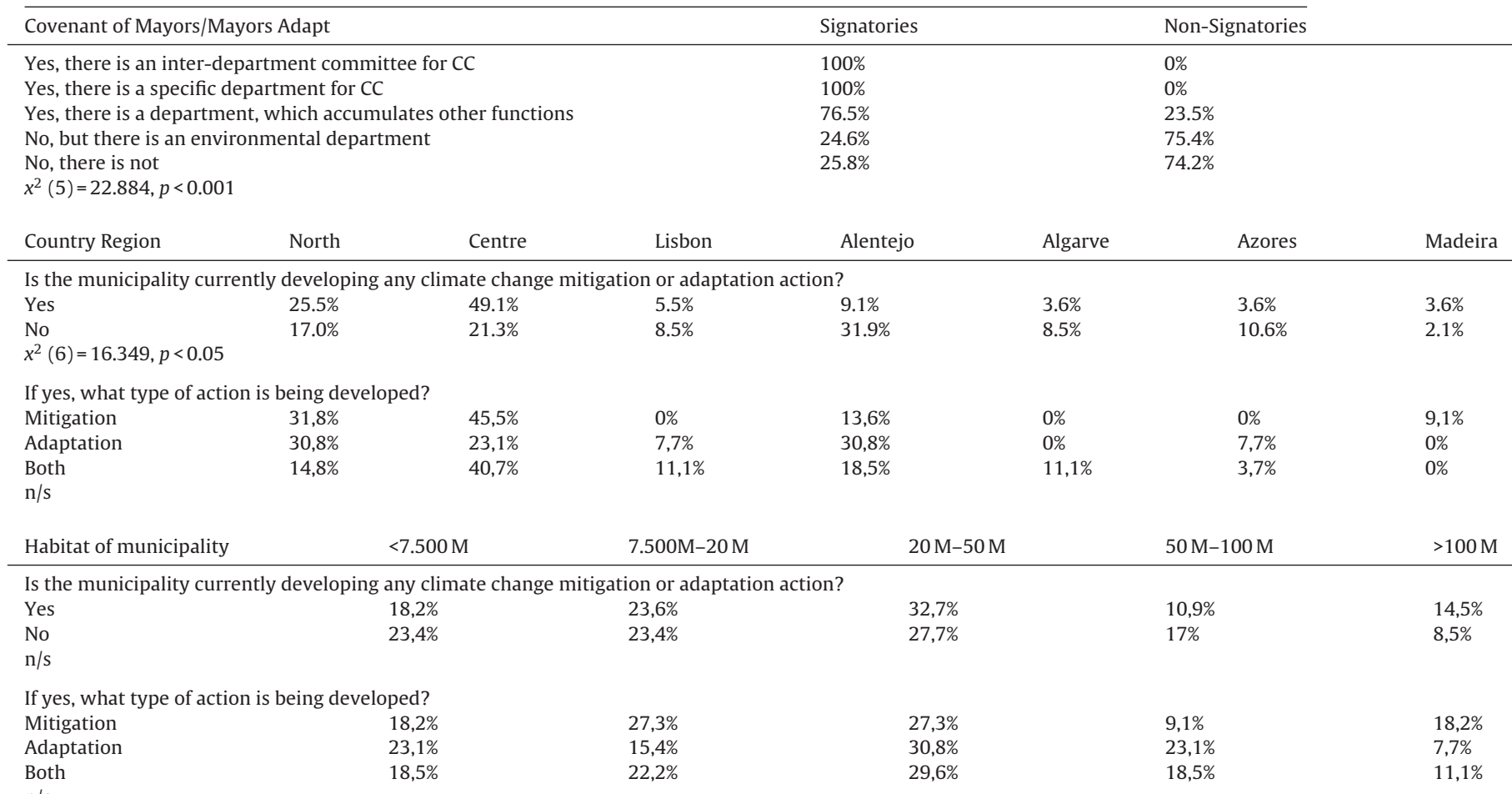

$\mathrm{n} / \mathrm{s}$

Signatories

Non-Signatories

Covenant of Mayors/Mayors Adapt

mitigation or adaptation action?

Is the municipality currently developing any climate change mitigation
Yes $45,5 \%$

$\begin{array}{llr}\text { Yes } & 45,5 \% & 54,5 \% \\ \text { No } & 19,1 \% & 80,9 \%\end{array}$

$\mathrm{n} / \mathrm{s}$

If yes, what type of action?

Mitigation

$54,5 \% \quad 45,5 \%$

Adaptation $\quad 46,2 \% \quad 53,8 \%$

$\begin{array}{lll}\text { Both } & 40,7 \% & 59,3 \%\end{array}$

$\mathrm{n} / \mathrm{s}$

What Policy Instrument was most relevant for planning and/or implementing climate change actions?

\begin{tabular}{|c|c|c|c|c|c|c|c|}
\hline Country Region & North & Centre & Lisbon & Alentejo & Algarve & Açores & Madeira \\
\hline Municipal Strategic Plans for CC & $16,7 \%$ & $16,7 \%$ & $16,7 \%$ & $33,3 \%$ & $0 \%$ & $16,7 \%$ & $0 \%$ \\
\hline National Adaptation Strategy & $18,2 \%$ & $50,0 \%$ & $13,6 \%$ & $9,1 \%$ & $0,0 \%$ & $0,0 \%$ & $9,1 \%$ \\
\hline European Adaptation Strategy & $40,0 \%$ & $20,0 \%$ & $20,0 \%$ & $0,0 \%$ & $20,0 \%$ & $0,0 \%$ & $0,0 \%$ \\
\hline Other & $66,7 \%$ & $33,3 \%$ & $0,0 \%$ & $0,0 \%$ & $0,0 \%$ & $0,0 \%$ & $0,0 \%$ \\
\hline
\end{tabular}

$\mathrm{n} / \mathrm{s}$

What Policy Instrument was most relevant for planning and/or implementing climate change actions?

\begin{tabular}{|c|c|c|c|c|c|}
\hline Habitat of Municipality & $<7.500 \mathrm{M}$ & $7.500 \mathrm{M}-20 \mathrm{M}$ & $20 \mathrm{M}-50 \mathrm{M}$ & $50 \mathrm{M}-100 \mathrm{M}$ & $>100 \mathrm{M}$ \\
\hline Municipal Strategic Plans for CC & $0 \%$ & $33,3 \%$ & $16,7 \%$ & $33,3 \%$ & $16,7 \%$ \\
\hline National Adaptation Strategy & $0 \%$ & $27,3 \%$ & $36,4 \%$ & $22,7 \%$ & $17.20 \%$ \\
\hline European Adaptation Strategy & $20 \%$ & $0 \%$ & $0 \%$ & $40 \%$ & $40 \%$ \\
\hline Other & $16,7 \%$ & $33,3 \%$ & $33,3 \%$ & $0,0 \%$ & $16,7 \%$ \\
\hline
\end{tabular}

$\mathrm{n} / \mathrm{s}$ 
Table 2 (Continued)

What Policy Instrument was most relevant for planning and/or implementing climate change actions?

\begin{tabular}{lll}
\hline Covenant of Mayors/Mayors Adapt & Signatories & Non-Signatories \\
\hline Municipal Strategic Plans for CC & $50 \%$ & $50 \%$ \\
National Adaptation Strategy & $50 \%$ & $50 \%$ \\
European Adaptation Strategy & $80 \%$ & $20 \%$ \\
Other & $83 \%$ & $16 \%$
\end{tabular}

Table 3

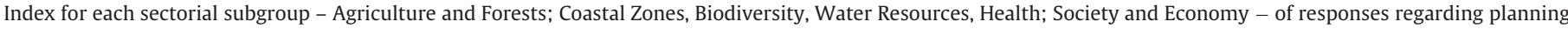
and implementation of measures.

\begin{tabular}{|c|c|c|c|c|c|c|c|c|}
\hline Sectors & Index & $\begin{array}{l}\text { No; no plans } \\
\text { are foreseen }\end{array}$ & $\begin{array}{l}\text { measures are } \\
\text { being studied }\end{array}$ & $\begin{array}{l}\text { A plan being } \\
\text { developed }\end{array}$ & $\begin{array}{l}\text { Measures are } \\
\text { being } \\
\text { implemented }\end{array}$ & $\begin{array}{l}\text { Measures } \\
\text { implemented } \\
\text { are being } \\
\text { assessed }\end{array}$ & $\begin{array}{l}\text { Don't } \\
\text { know/cannot } \\
\text { respond }\end{array}$ & $\begin{array}{l}\text { Mean value } \\
\text { (scale of } 1-5)\end{array}$ \\
\hline $\begin{array}{l}\text { Agriculture and } \\
\text { Forests }\end{array}$ & $\alpha=0.748$ & $5.5 \%$ & $21.1 \%$ & $21.1 \%$ & $7.3 \%$ & $2.8 \%$ & $42.2 \%$ & 2.7 \\
\hline Coastal zones & $\alpha=0.755$ & $11.5 \%$ & $15.4 \%$ & $15.4 \%$ & $19.2 \%$ & $0.0 \%$ & $38.5 \%$ & 2.7 \\
\hline Biodiversity & $\alpha=0.764$ & $13.8 \%$ & $14.7 \%$ & $9.2 \%$ & $4.6 \%$ & $0.0 \%$ & $57.8 \%$ & 2.1 \\
\hline $\begin{array}{l}\text { Water } \\
\text { resources }\end{array}$ & $\alpha=0.832$ & $22.0 \%$ & $22.9 \%$ & $7.3 \%$ & $0.0 \%$ & $2.8 \%$ & $55.0 \%$ & 1.9 \\
\hline Health & $\alpha=0.630$ & $17.4 \%$ & $20.2 \%$ & $4.6 \%$ & $2.8 \%$ & $0.0 \%$ & $55.0 \%$ & 1.9 \\
\hline $\begin{array}{l}\text { Society and } \\
\text { Economy }\end{array}$ & $\alpha=0.694$ & $18.3 \%$ & $16.5 \%$ & $10.1 \%$ & $0.0 \%$ & $49.5 \%$ & $18.3 \%$ & 2.6 \\
\hline
\end{tabular}

non-signatories, as well as between, Littoral and Inland municipalities (see Tables 2 and 3).

Explicitly about climate change adaptation, the survey asked if a strategy or plan was being developed or implemented by the municipality. Only $10.1 \%$ had an adaptation plan being implemented. Among other respondents, $70.6 \%$ claimed the municipality did not have a climate change adaptation strategy or action-plan, and $15.6 \%$ referred that a plan was being developed. Moreover, $3.7 \%$ claimed that adaptation measures were integrated in other plans, such as the municipal Environmental Plan. Concerning policy incentives for local action, the survey asked what policies or instruments were relevant models for their municipality. Response options included: the Portuguese National Adaptation Strategy (PNAS), a Municipal Strategic Plan (MSP), and the European Adaptation Strategy (EAS), as well as the option, "other". The PNAS was the most referred instrument, with $56.4 \%$ responses. $15.4 \%$ responses pointed to the importance of a having a municipal strategy, and an equal number referred to 'other' - specifying the importance of being a member of European networks such as the Covenant of Mayors and Mayors Adapt program. Lastly, Signatories of the Covenant of Mayors/Mayors Adapt attributed far more importance (80\%) to the European Strategy, when compared with non-signatories (20\%) (see Table 2).

\subsection{Climate policy and actions in portuguese municipalities}

Respondents were asked to state if any three actions (related to mitigation and adaptation, or both) had been implemented. Since this was an open question, results were codified based on a matrix with ten thematic categories, listed in Fig. 1. Among the options given, participants mainly mentioned actions related to mitigation policies under the categories: 'efficient management of buildings' and 'public lighting'. As regards to adaptation, the main type of actions referred, related to the 'plans, alert systems and risk management' category.

The categories and the habitat of the municipality were aggregated to show the predominance of some types of actions implemented. For instance, responses referring 'plans, alerts systems and risk' (e.g. heat wave alert systems) predominated (55.6\%) in municipalities with less than 7500 inhabitants. Municipalities with 7500 and 20,000 residents, mainly highlighted measures or actions related to developing an 'efficient management of municipal buildings' (78.6\%). Municipalities with a population between 20,000 and 50,000 inhabitants, centred their responses on the topics of 'sustainable urban mobility' (83.3\%) and 'renovation of the municipal fleet and road management' (50\%). Sustainable mobility is frequently mentioned by municipalities with more than 100,000 inhabitants. The latter referred also to actions concerning the development of 'plans, alert systems and risks' ( $83.3 \%$ ), and $50 \%$ of actions reported in this group are under the category of 'collecting and disseminating information'.

The Littoral prioritized actions related to 'plans, alert systems and risks' (52.9\%), as well as, 'sustainable urban mobility' (52.9\%); while Inland regions emphasized actions related to 'efficient management of municipal buildings' (59.5\%) and 'efficient public lighting' (48.2\%).

To identify the scope of climate change actions (mitigation, adaptation or both) that municipalities found important to implement in the medium term, the respondents were asked to specify three types of actions. Results were codified based on a matrix with ten thematic categories, as shown in Fig. 2.

Participants were asked to point out what their main concerns were regarding possible impacts of climate change in their region. Top concerns were: 'increase of extreme weather events and season shift' (42.9\%), and 'rising sea level' (35.7\%).

\subsubsection{Climate change adaptation measures implemented}

Regarding adaptation measures, the survey asked what measures were implemented or were being implemented. This question was sub-divided into six sectorial subgroups, namely measures for: agriculture and forests, coastal zones, biodiversity, water resources, health, society and economy. For each subgroup a number of multichoice options was given. For instance, for coastal zones, options included: alert systems, prevention of extreme weather events, monitoring flood levels. Response categories included: (1) 'No; and no plans are foreseen'; (2) 'Possible measures are being studied'; (3) 'A plan is being developed'; (4) 'Measures are being implemented'; (5) 'Measures have been implemented and are being assessed'; and 'don't know/cannot respond'. An index was created based on the responses for each subgroup, in order to compare results between the different sectorial groups of measures. Table 3 shows these results for each sectorial subgroup. 


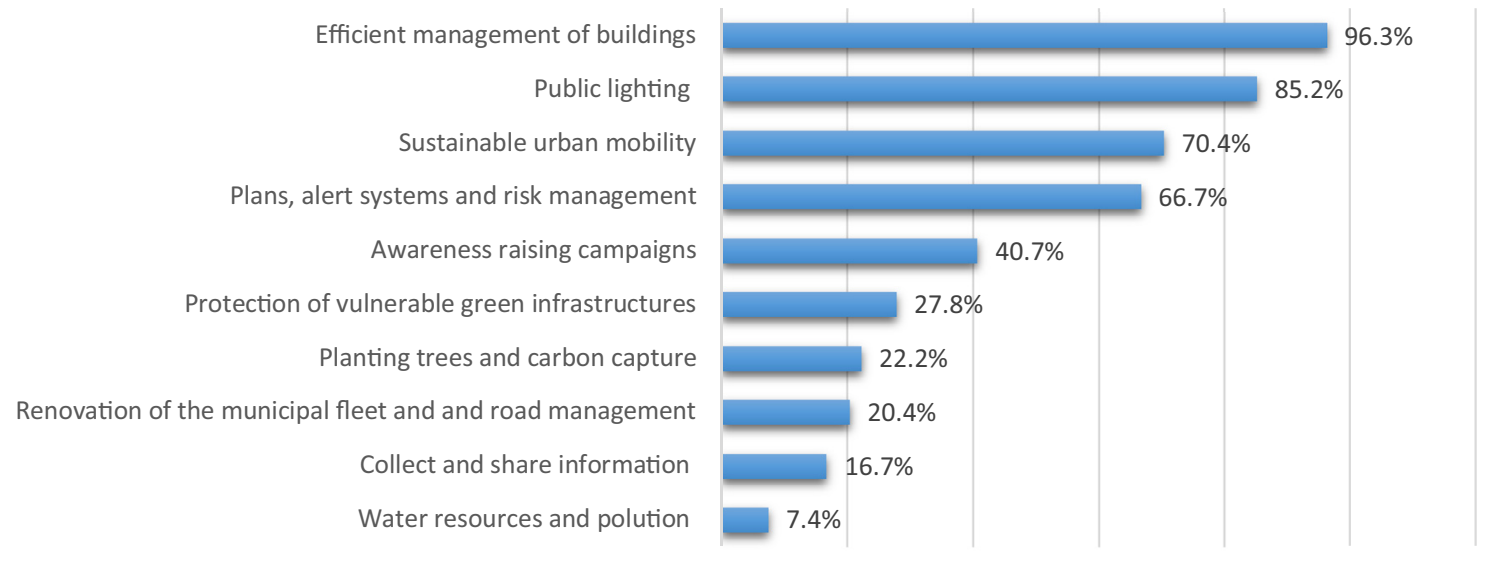

Fig. 1. Mitigation and Adaptation Actions being implemented in Portuguese municipalities, codified under ten thematic categories.

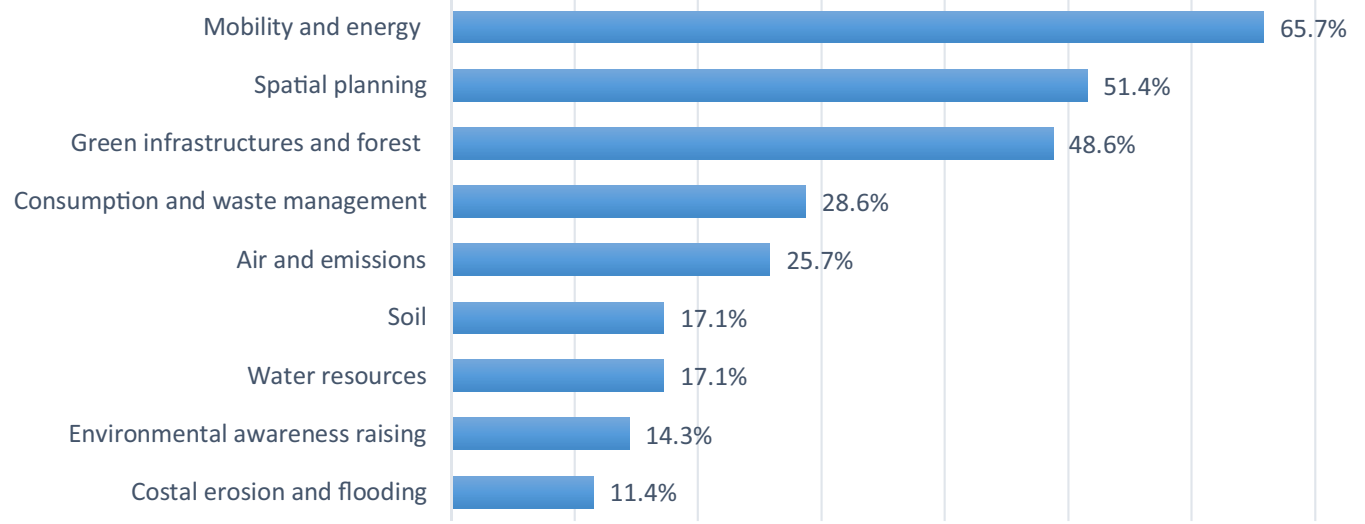

Fig. 2. Main categories of climate change measures which municipalities would like to implement in the medium term, codified under 10 thematic categories.

Every sectorial group had a high number of responses in the categories 'no, and no plans are foreseen' and 'don't know/cannot respond' ( $>80 \%$ of responses), resulting in a low level of valid responses. These findings reveal there are very few adaptation measures currently being planned or implemented. Nevertheless, water related measures (in costal zones and water resources subgroups), environmental education programs and civil protection (in the society and economy subgroup) are the most common among those being implemented.

\subsubsection{Factors triggering action on climate change}

Respondents were asked to choose, among a set of triggers for local action, which were triggering specific climate change adaptation actions. At the national level, the top 2 relevant triggers were 'civic awareness of the importance to act' and 'future impacts expected for the region'. There were significant differences in the triggers between Littoral and Inland municipalities. In the Littoral the main triggers were 'future expected impacts for the region' and 'escalation of existent problems'. Although these are equally important for Inland regions there is a difference of respectively $23.3 \%$ and $43 \%$ in the two categories as shown in Table 4.

\subsubsection{Development factors encouraging decisions to act}

Regarding development factors encouraging the decision to act on climate change, Table 5 shows the mean values attributed to each factor. Although 'protection and security' have ranked first, 'political will' and 'economic development' appear with high mean values (on a scale of 1 - 'not an important factor' to 6 - 'very Important factor'), while 'civil society pressure' appears with the lowest mean value.

At the regional level, Littoral municipalities ranked high on stating 'geographic vulnerability' as a driver for action, as the majority (60\%) responded that this was a 'very important factor'. Conversely, $58.5 \%$ of Inland regions considered 'geographic vulnerability' as being an 'important factor' (5) or a 'very important factor' (6). Similarly, 'climatic vulnerability' has a higher concentration of

Table 4

Triggers leading local action in Portuguese Mainland and Islands, comparison of Littoral and Inland municipalities.

\begin{tabular}{|c|c|c|c|}
\hline Triggers & National & Littoral & Inland \\
\hline Future expected impacts for the region & $55.0 \%$ & $61.5 \%$ & $38.2 \%$ \\
\hline Escalation of existent problems & $45.0 \%$ & $61.5 \%$ & $18.4 \%$ \\
\hline Experienced and perceived impacts in the region & $30.0 \%$ & $38.5 \%$ & $23.7 \%$ \\
\hline Social awareness of the importance to act & $28.0 \%$ & $30.8 \%$ & $61.8 \%$ \\
\hline Available financial mechanisms & $24.0 \%$ & $15.4 \%$ & $23.7 \%$ \\
\hline Results of scientific research & $22.0 \%$ & $11.5 \%$ & $1.3 \%$ \\
\hline Member of (national) municipal networks concerned with the topic & $4.0 \%$ & $7.7 \%$ & $28.9 \%$ \\
\hline
\end{tabular}


Table 5

Development goals encouraging the municipalities' decision to act on climate change at the national level (mean values between 1- not an important factor to 6-very important factor)

\begin{tabular}{ll}
\hline $\begin{array}{l}\text { Development goals } \\
\text { encouraging decision to act } \\
\text { on climate change }\end{array}$ & Mean value[1-6] \\
\hline Protection and security & 5.2 \\
Political will & 4.8 \\
Economic development & 4.7 \\
Geographic vulnerability & 4.4 \\
Conservation of the & 4.3 \\
patrimony & \\
Climatic vulnerability & 4.2 \\
Equity and social justice & 4.1 \\
Pressure from civil society & 3.8 \\
\hline
\end{tabular}

responses in the Littoral, with $96 \%$ of responses in categories 5 and 6 , compared to $62 \%$ of responses in the same categories for Inland regions. However, 'political will' is equally important in both regions. The weight attributed to 'political will' increases according to the habitat (number of inhabitants) of municipalities.

\subsection{Information and knowledge}

\subsubsection{Information on climate change}

Concerning the level of information on climate change and sustainable development, $81.6 \%$ responded in the categories 'no available information' (1); 'little information' (2); and 'some information' (3). Municipalities with a higher number of inhabitants (i.e. $>50,000$ residents) claimed to have more information on climate change and sustainable development. Yet, the most relevant difference when crossing these data with other variables is between the municipalities developing mitigation or adaptation actions and those not developing any policy or actions related to climate change. Those developing actions are better informed, although most municipalities stated a lack of information (see Table 6). As for the sources of information, the internet is the most used source (70.4\%), followed by information provided by public administration services (36.6\%), and scientific publications and studies (32.4\%), as shown in Fig. 3.

\subsubsection{Knowledge on climate change}

Concerning the level of knowledge on climate change issues, namely on global impacts, local impacts, mitigation and adaptation measures, responses were predominantly in the categories: (1) 'no knowledge', and (2) 'little knowledge'. The level of knowledge on climate change impacts and measures appears to depend on the structures already existent within the municipality. Lack of knowledge on climate change impacts at the local level was greater when there was not a specific department. Conversely, the level of knowledge reported was higher in the municipalities with a special department. Finally, there were clear differences between the level of knowledge in municipalities with a special department or commission for climate change and those where climate change issues are dealt with by an environmental department (see Table 6).

\section{Discussion}

An analysis of the survey's findings confirms the hypothesis that local polities are not appropriately involved nor guided by National and European strategies. Yet, climate change mitigation and adaptation appear to be less important at the local level than hypothesized. In Portugal, municipalities generally do not find climate change to be an important issue. Those municipalities developing mitigation and/or adaptation programs are better equipped to do so and have a special department or commission leading the process. The absence of appropriate organisational structures, which occurs mostly in Inland small municipalities, where social capital is scarce, is likely to compromise effective policy-making processes (Hunt and Watkiss, 2011). National and European adaptation strategies seem to hold some influence on local planning agendas. However, both strategies are non-binding policies and do not provide clear guidelines for local level adaptation. Yet, guidance is important, and local institutional attention to adaptation is highly driven by central government strategies (Baker et al., 2012; Dannevig et al., 2012).

'Future impacts expected for the region' were the second highest trigger for action. However, to learn about future impacts in their region, municipalities will need to develop robust studies on local risks and vulnerabilities. These studies should include downscaling socio-economic and climate change scenarios to address contextual specificities (Berkhout et al., 2014) and producing local climate predictions (Sein et al., 2014; Dias and Alves, 2013). The downscaling of climate scenarios should equally account for local climate diversity (Stewart and Oke, 2012; Lenoir et al., 2013), and how climatic changes could affect different areas and sectors within municipal boundaries (Flint and Flint, 2012; Niles et al., 2015). Other relevant factors indirectly related to climate change (e.g. erosion, land degradation) should equally be considered. Once a detailed prediction of local climatic changes is presented, planning adaptation can be a complex process (Wise et al., 2014). A multi-method approach is important to develop sustainable adaptation plans, which can benefit from using Geographic Information System maps and provide local stakeholders with a clear visual representation of risks (Wood

Table 6

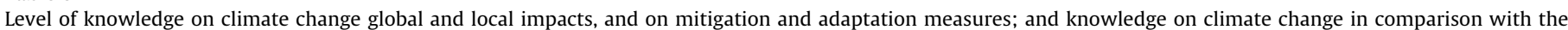
existence of a specific department/commission for climate change issues.

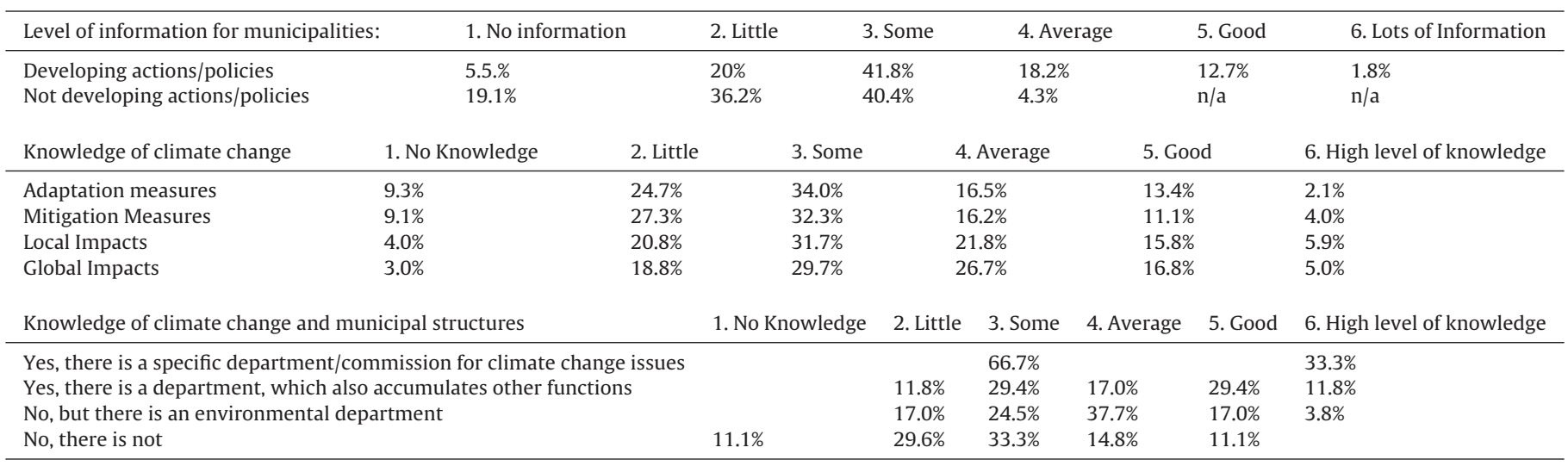




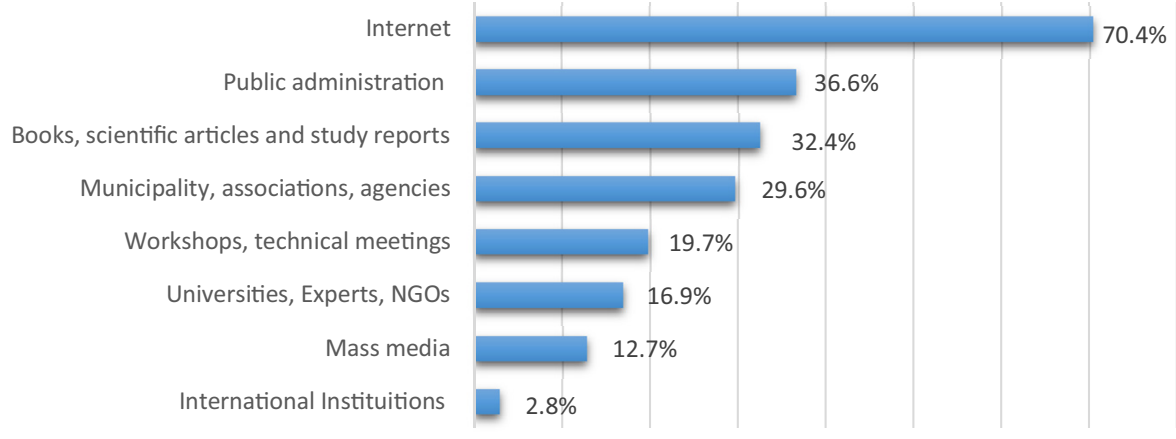

Fig. 3. Sources of Information regarding climate change impacts, adaptation, and mitigation.

and Stocker, 2009; Campos et al., 2016b). Once potential measures are identified, the planning process could include a prioritization of measures and an assessment of costs and benefits, taking into account future climatic uncertainties and the social and environmental impacts of different measures (Hallegatte, 2009; Haasnoot et al., 2013). Despite the need for these climate studies and services, Portuguese municipalities seem to be unrealistic concerning the depth and scope of research required to produce effective local responses. It is likely that the majority cannot adequately assess local climate change impacts, which may generally justify the low importance attributed to the issue. In addition, these studies may be too expensive for most. In Portugal, the two richest municipalities (Cascais and Sintra) are also the most advanced in their climate change policies and each has spent an average of 150.000 euros in research on local impacts and adaptation (Carvalho et al., 2015).

Lack of knowledge and information, lack of access to funding sources and the nature of mitigation versus adaptation actions may explain also why adaptation weighs less than mitigation in the Portuguese case. Richer municipalities with a higher number of inhabitants (Schmidt and Guerra, 2010), are more prone to devise a climate change strategy, possibly because they have more resources, and access to available information and knowledge. Project funding is among the most important financing mechanism for adaptation in European countries and tends to be mainly targeted at implementing measures (EEA, 2015:9). When applying for funds, municipalities should have already invested in developing a risk and vulnerability assessment, and have knowledge on potential adaptation measures. Uncertainty and lack of knowledge make it harder to measure progress on adaptation, which is equally important for financing measures (Ford et al., 2013). Therefore, richer municipalities are likely to be better equipped to receive extra funds for adaptation. The low importance attributed to adaptation in comparison with mitigation may also be explained by the fact that mitigation seems to be better understood and have a more immediate outcome and short-term policy guidance (Carvalho et al., 2014). Conversely, adaptation is likely to have a long-term goal (Pelling, 2010) and may be more challenging for policymakers, given election dynamics; but also due to a tendency for a short-term focus, and a perception that threats are not eminent and can be dealt with at a later time (Füssel, 2007; Berrang-Ford et al., 2011).

Among the municipalities developing climate change policies and actions, the role of European networks has been highlighted, through the examples of the Covenant of Mayors and the Mayors Adapt initiatives. Signatories of these networks are more prone to developing climate change policies and actions, and appear better prepared, from the administrative and institutional point of view, and better informed to respond and develop both mitigation and adaptation strategies. Yet, these networks have been found to be 'pioneers for pioneers' (Kern and Bulkeley, 2009: 309). It's difficult to assess whether members of transnational networks joined because they were more progressive or became pioneers in climate policies due to the influence of the networks. Signatories of networks are also among the richest municipalities, which raises the question of equity. Transnational networks offer sources of knowledge exchange and information, as well as opportunities for project funding (Betsill and Bulkeley, 2004). If being a member is a result of being a richer and a more progressive municipality, it seems important to reach out to smaller municipalities, who may be less able to finance local studies, and can benefit from the shared knowledge, experiences, lessons learned, and funding, which is provided through these networks. Lastly, since the dominant source of information is the internet, it seems important to deliver web-based open source publications, methods, tools and research data on climate change.

As a driver for action and as a trigger for policy making, public participation appears with low values. Municipal policy makers and planners, although recognizing the importance of 'political will' in promoting climate change action, attribute a low importance to 'participation and civil society'. These results reinforce findings from other studies, which concluded top policies in Portugal have not been publicized, nor discussed or validated by society at large (O'Riordan et al., 2014; Carvalho et al., 2014). The absence of stakeholder engagement results in a poor social basis of support for the existent policies and plans. Portuguese municipalities are neither benefiting from a clear vertical guidance (e.g. specific guidelines from the National Adaptation Strategy), nor from partnerships with a wider set of social actors, such as civil society groups, local residents or business owners. Therefore, there is a clear opportunity for a stronger interaction with social actors at multiple scales and levels of governance (Adger et al., 2005) in order to support the build-up of social capital (Adger, 2003; Juhola and Westerhoff, 2011).

The survey provides equally some insights into cultural differences, rooted in the characteristics of space attachments (Adger et al., 2011) between Littoral and Inland regions. Recent studies, done in Portuguese coastal communities, indicate a growing awareness of the vulnerabilities and risks regarding climate change (O'Riordan et al., 2014; Schmidt et al., 2014). Not surprisingly, coastal regions gave more importance to 'future expected impacts for the region' and 'escalation of existent problems' as triggers for action, when compared with Inland regions. Results show adaptation is more important to coastal municipalities, and mitigation to Inland. The Portuguese Northern Atlantic coast is already experiencing some degree of climate change impacts. As the severe winters of 2014 left several areas flooded; vulnerabilities and risks (not previously considered as important) are now hitting coastal regions. The Portuguese media have no doubt played an important role in framing this issue (Schmidt et al., 2014), although fomenting climate change responses from a technical, managerial and global perspective (Carvalho et al., 2014). Conversely, Inland regions in the Portuguese mainland have always dealt with climatic changes affecting soil productivity, and with social and ecological 
consequences, such as, land abandonment, rural exodus and land degradation (Truninger and Freire, 2014). Coastal communities, however, are faced increasingly with the possibility of impacts that threaten their way of life. Considering that the practice of adapting to a changing environment is embedded in local cultural meanings (Flora, 1998), climate can be a meaning attributed to place (Knez, 2005), and therefore a motivator for thinking about adaptation as a way of deterring the future and the undesirable possibility of relocation in coastal areas. Conversely, over the past decades, Inland regions in Portugal have dealt with rural exodus and land abandonment problems (Truninger and Freire, 2014), resulting in a lack of social capital that hinders civil society and municipal action. In this context a changing climate is a concern that may aggravate wellknown land use problems, but would not be enough to challenge local cultural perceptions of deeply aged and dependent communities (Schmidt and Guerra, 2010). Thus, the land in rural regions will continue to be perceived as a vulnerable and unforeseeable territory (Ambrosio-Albalá and Bastiaensen, 2010; Cheshire et al., 2015).

\section{Conclusion}

In Portugal, the importance of climate change in the municipal policy agendas varies between North and South, Littoral and Inland regions, and between municipalities with a higher number of inhabitants and those with less inhabitants, as well as between, signatories and non-signatories of the Covenant of Mayors and Mayors Adapt initiatives. European and national strategies should provide clear guidance for municipalities on how to design and implement mitigation and adaptation actions. Participation is not being valued by municipalities as a driver for climate change policies. There is still an untapped potential for building social capital by promoting multilevel policy guidance and multi-stakeholder partnerships. European and National strategies should encourage participation and promote the mainstreaming of the climate change topic across social groups, from political, to civil society and market spheres.

Interest in climate change seems to be higher when municipalities benefit from knowledge, material and immaterial resources that inform and support policy-making. Transnational networks could reach out to smaller and less progressive municipalities as a strategy in raising awareness of climate change, and support the implementation of policies in more vulnerable regions through project funding.

Future studies should map knowledge and technical needs (e.g. local risk and vulnerability assessments, economic and multi-criteria assessments of measures, participatory planning of adaptation) and produce a needs-based assessment of climate services and studies for upholding climate change strategies in municipalities.

Rather than representing mere technical fixes, responses to climate change at the local level have the potential to incrementally shape policy pathways towards more sustainable outcomes. Considering the geographic differences across the country, the analysis of climate policies and actions in the Portuguese case indicates the material, technocratic dimensions of responding to climate change (i.e. through mitigation and/or adaptation policy and measures) are conceptualized under the scope of immaterial perceptions and values, which influence local interests and the decisions to act. Different cultural perceptions on the impacts of climate change on the local way of life, constrained by differing socio-economic conditions, appear to be influencing the type of responses between coastal and inland regions. Other European countries, particularly those facing similar impacts with Atlantic coastal regions and/or Mediterranean inland regions, should consider how to address climate change, while taking into account how cultural perceptions and attachments to places may be either enablers or barriers to taking action.

\section{Acknowledgements}

The authors would like to thank all those who responded to this survey. The authors thank the European Commission for the funding of the FP7 project "Bottom-up Climate Adaptation Strategies towards the Sustainable Europe" (Grant Agreement 308337), under which this survey was developed. The authors equally thank the Fundação para a Ciência e Tecnologia for the financial support of Gil Penha-Lopes (scholarship SFRH/BPD/65977/2009), of Filipe Alves (PD/BD/113934/2015) and André Vizinho (grant PD/PB/113929/2015), and of Ce3C (Ref.UID/BIA/00329/2013). The research developed has not in been influenced by the funding received, and the article does not reflect in any form the opinions of the funding institutions.

\section{References}

Adger, W.N., Arnell, N.W., Tompkins, E.L., 2005. Successful adaptation to climate change across scales. Global Environ. Change 15 (2), 77-86, http://dx.doi.org/ 10.1016/j.gloenvcha.2004.12.005.

Adger, W.N., Barnett, J., Chapin III, I.F.S., Ellemor, H., 2011. This must be the place: underrepresentation of identity and meaning in climate change decision-making. Global Environ. Pol. 11 (2), 1-25, http://dx.doi.org/10.1016/j. jenvp.2005.03.003.

Adger, W.N., Barnett, J., Brown, K., Marshall, N., O’Brien, K., 2012. Cultural dimensions of climate change impacts and adaptation. Nat. Clim. Change 3 (2), 112-117, http://dx.doi.org/10.1038/NCLIMATE1666.

Adger, W.N., 2003. Social capital, collective action, and adaptation to climate change. In: Der Klimawandel. VS Verlag für Sozialwissenschaften, pp. 327-345, http://dx.doi.org/10.1007/978-3-531-92258-4_19.

Agarwal, A., Perrin, N., Chatre, A., Benson, C.S., Kononen, M., 2012. Climate policy processes, local institutions, and adaptation actions: mechanisms of translation and influence. Wiley Interdiscip. Rev. Clim. Change 3 (6), 565-579, http://dx.doi.org/10.1002/wcc.193.

Amaru, S., Chhetri, N.B., 2013. Climate adaptation: institutional response to environmental constraints, and the need for increased flexibility, participation, and integration of approaches. Appl. Geogr. 39, 128-139, http://dx.doi.org/10. 1016/j.apgeog.2012.12.006.

Ambrosio-Albalá, M., Bastiaensen, J., 2010. The New Territorial Paradigm of Rural Development: Theoretical Foundations from Systems and Institutional Theories. IOB, Available from: http://www.researchgate.net/profile/Mateo Ambrosio-Albala/publication/228381936_The_new_territorial_paradigm_of rural_development_theoretical_foundations_from_systems_and_institutional_ theories/links/54227c000cf238c6ea67a7d8.pdf.

Amundsen, H., Berglund, F., Westskog, H., 2010. Overcoming barriers to climate change adaptation-a question of multilevel governance? Environ. Plann. C: Govern. Policy 28 (2), 276-289.

Armitage, D., Marschke, M., Plummer, R., 2008. Adaptive co-management and the paradox of learning. Global Environ. Change 18 (1), 86-98, http://dx.doi.org/ 10.1016/j.gloenvcha.2007.07.002.

Baker, I., Peterson, A., Brown, G., McAlpine, C., 2012. Local government response to the impacts of climate change: an evaluation of local climate adaptation plans. Landscape Urban Plann. 107 (2), 127-136, http://dx.doi.org/10.1016/j. landurbplan.2012.05.009.

Berkhout, F., van den Hurk, B., Bessembinder, J., de Boer, J., Bregman, B., van Drunen, M., 2014. Framing climate uncertainty: socio-economic and climate scenarios in vulnerability and adaptation assessments. Reg. Environ. Change 14 (3), 879-893, http://dx.doi.org/10.1007/s10113-013-0519-2.

Berrang-Ford, L., Ford, J.D., Paterson, J., 2011. Are we adapting to climate change? Global Environ. Change 21 (1), 25-33, http://dx.doi.org/10.1016/j.gloenvcha. 2010.09.012.

Betsill, M.M., Bulkeley, H., 2004. Transnational networks and global environmental governance: the cities for climate protection program. Int. Stud. Q. 48 (2), 471-493.

Brooks, N., Adger, W.N., Kelly, P.M., 2005. The determinants of vulnerability and adaptive capacity at the national level and the implications for adaptation. Global Environ. Change 15 (2), 151-163, http://dx.doi.org/10.1016/j.gloenvcha. 2004.12.006.

Bulkeley, H., 2010. Cities and the governing of climate change. Annu. Rev. Environ. Resour. 35, 229-253, http://dx.doi.org/10.1146/annurev-environ-072809101747.

Campos, I., Alves, F.M., Dinis, J., Truninger, M., Vizinho, A., Penha-Lopes, G., 2016a. Climate adaptation, transitions, and socially innovative action-research approaches. Ecol. Soc. 21, 13 http://www.ecologyandsociety.org/vol21/iss1/ art13/.

Campos, I., Vizinho, A., Coelho, C., Alves, F., Truninger, M., Pereira, C., Santos, F.D., Lopes, G. Penha, 2016b. Participation, scenarios and pathways in long-term 
planning for climate change adaptation. Plann. Theory Pract., 1-20, http://dx. doi.org/10.1080/14649357.2016.1215511.

Carvalho, A., Schmidt, L., Santos, F.D., Delicado, A., 2014. Climate change research and policy in Portugal. Wiley Interdiscip. Rev. Clim. Change 5, 199-217, http:// dx.doi.org/10.1002/wcc.258.

Carvalho, J., Fernandes, M.J., Camões, P., Jorge, S., 2015. Anuário Financeiro Dos Municípios Portugueses [Financial Annuity of Portuguese Municipalities]. Edição da Ordem dos Contabilistas Certificados, Lisbon.

Cash, D.W., Adger, W.N., Berkes, F., Garden, P., Lebel, L., Olsson, P., . . . Pritchard L., andYoung, O., 2006. Scale and cross-scale dynamics: governance and information in a multi-level world. Ecol. Soc. 11 (2), 8 http://www. ecologyandsociety.org/vol11/iss2/art8/.

Cheshire, L., Esparcia, J., Shucksmith, M., 2015. Community resilience, social capital and territorial governance. Ager: Revista de estudios sobre despoblación y desarrollo rural = J. Depopul. Rural Dev. Stud. 18, 7-38, http://dx.doi.org/10 4422/ager.2015.0.

Ciscar, J.C., Iglesias, A., Feyen, L., Szabó, L., Van Regemorter, D., Amelung, B., Nicholls, R., Watkiss, P., Christensen, O.B., Dankers, R., Garrote, L., Goodess, C.M., Hunt, A., Moreno, A., Richards, J., Soria, A., 2011. Physical and economic consequences of climate change in Europe. Proc. Natl. Acad. Sci. 108 (7), 2678-2683, http://dx.doi.org/10.1016/j.agwat.2015.03.014.

Dannevig, H., Rauken, T., Hovelsrud, G., 2012. Implementing adaptation to climate change at the local level. Local Environ. 17 (6-7), 597-611, http://dx.doi.org/10. 1080/13549839.2012.678317 http://hdl.handle.net/10535/3412.

Dias, J.M., Alves, F.L., 2013. Risco De Cheias E Estratégias De Adaptação Para a Zona Costeira E Lagunar Da Ria De Aveiro. [Flood Risks and Adaptation Strategies for the Coastal Zone and the Ria De Aveiro Lagoon.]. Aveiro University: CESAM Centro de Estudos do Ambiente e do Mar, Retrieved from: http://la.cesam.ua. pt/Documentos/Risco_de_Cheia.pdf.

EEA [European Environmental Agency], 2014. National Adaptation Policy Processes in European Countries. Report No 4/2014, Available from: http:// www.eea.europa.eu/publications/national-adaptation-policy-processes.

EEA [European Environmental Agency], 2015. National Monitoring, Reporting and Evaluation of Climate Change Adaptation in Europe. Report N020/2015, Available from: http://www.eea.europa.eu/publications/national-monitoringreporting-and-evaluation.

Füssel, H.M., 2007. Adaptation planning for climate change: concepts, assessment approaches, and key lessons. Sustainability Sci. 2 (2), 265-275, http://dx.doi. org/10.1007/s11625-007-0032-y.

Flint, L.E., Flint, A.L., 2012. Downscaling future climate scenarios to fine scales for hydrologic and ecological modeling and analysis. Ecol. Processes 1 (1), 1 , http://dx.doi.org/10.1186/2192-1709-1-2.

Flora, J.L., 1998. Social capital and communities of place. Rural Sociol. 63 (4), 481-506, http://dx.doi.org/10.1111/j.1549-0831.1998.tb00689.x.

Folke, C., Hahn, T., Olsson, P., Norberg, J., 2005. Adaptive governance of social-ecological systems. Ann. Rev. Environ. Resour. 30 (1), 441-473, http:// dx.doi.org/10.1146/annurev.energy.30.050504.144511.

Folke, C., Carpenter, S.R., Walker, B., Scheffer, M., Chapin, T., Rockström, J., 2010. Resilience thinking: integrating resilience, adaptability and transformability. Ecol. Soc. 15 (4), 20, Available online at: http://www.ecologyandsociety.org/ vol15/iss4/art20/.

Folke, C., 2006. Resilience: the emergence of a perspective for social-ecological systems analyses. Global Environ. Change 16, 253-267, http://dx.doi.org/10. 1016/j.gloenvcha.2006.04.002.

Ford, J.D., Berrang-ford, L., Lesnikowski, A., Barrera, M., Heymann, S.J., 2013. How to track adaptation to climate change: a typology of approaches for national-level application. Ecol. Soc. 18 (3), 40, http://dx.doi.org/10.5751/ES-05732-180340.

Haasnoot, M., Kwakkel, J.H., Walker, W.E., Maat, J., 2013. Dynamic adaptive policy pathways: a method for crafting robust decisions for a deeply uncertain world. Global Environ. Change 23, 485-498, http://dx.doi.org/10.1016/j.gloenvcha. 2012.12.006.

Hallegatte, S., Przyluski, V., Vogt-Schilb, A., 2011. Building world narratives for climate change impact, adaptation and vulnerability analyses. Nat. Clim. Change 1 (3), 151-155, http://dx.doi.org/10.1038/nclimate1135.

Hallegatte, S., 2009. Strategies to adapt to an uncertain climate change. Global Environ. Change 19 (2), 240-247, http://dx.doi.org/10.1016/j.gloenvcha.2008. 12.003.

Hunt, A., Watkiss, P., 2011. Climate change impacts and adaptation in cities: a review of the literature. Clim. Change 104 (1), 13-49, http://dx.doi.org/10. 1007/s10584-010-9975-6.

INE [National Statistics Institute], 2011. Synthesis Reports, National Population Census, Available from: http://censos.ine.pt/xportal/ xmain? xpid=CENSOS\&xpgid=censos_ficheirosintese (last accessed on July, 2015).

Juhola, S., Westerhoff, L., 2011. Challenges of adaptation to climate change across multiple scales: a case study of network governance in two European countries. Environ. Sci. Policy 14 (3), 239-247, http://dx.doi.org/10.1016/j. envsci.2010.12.006.
Kay, A., 2006. Social Capital, the social economy and community development. Commun. Dev. J. 41 (2), 160-173, http://dx.doi.org/10.1093/cdj/bsi045.

Kern, K., Bulkeley, H., 2009. Cities, Europeanization and multi-level governance: governing climate change through transnational municipal networks. JCMS: J. Common Market Stud. 47 (2), 309-332.

Knez, I., 2005. Attachment and identity as related to a place and its perceived climate. J. Environ. Psychol. 25 (2), 207-218, http://dx.doi.org/10.1016/j.jenvp. 2005.03.003.

Lebel, L., Anderies, J.M., Campbell, B., Folke, C., Hatfield-Dodds, S., Hughes, T.P., Wilson, J., 2006. Governance and the capacity to manage resilience in regional social-ecological systems. Ecol. Soc. 11 (1), 19, Available online at: http:// digitalcommons.library.umaine.edu/cgi/viewcontent. cgi? article $=1051$ \& context=sms_facpub.

Lenoir, J., Graae, B.J., Aarrestad, P.A., Alsos, I.G., Armbruster, W.S., Austrheim, G., Bergendorff, C., Birks, H.J.B., Bråthen, K.A., Brunet, J., Bruun, H.H., Dalhberg, C.J., Decocq, G., Diekmann, M., Dynesius, M., Ejrnæs, R., Grytnes, J., Hylander, K., Klanderud, K., Luoto, M., Milbau, A., Moora, M., Nygaard, B., Odland, A., Ravolainen, V.T., Reinhardt, S., Sandvik, S.M., Høistad Schei, F., Speed, J.D., Tveraabak, L.U., Vandvik, V., Velle, L.G., Virtanen, M.Z., Svenning, J.-C., 2013. Local temperatures inferred from plant communities suggest strong spatial buffering of climate warming across Northern Europe. Global Change Biol. 19 (5), 1470-1481, http://dx.doi.org/10.1111/gcb.12129.

Lenschow, A., 2002. Environmental Policy Integration: Greening Sectoral Policies in Europe. Routledge, London.

Niles, M.T., Lubell, M., Brown, M., 2015. How limiting factors drive agricultural adaptation to climate change. Agric. Ecosyst. Environ. 200, 178-185, http://dx. doi.org/10.1016/j.agee.2014.11.010.

O'Riordan, T., Gomes, C., Schmidt, L., 2014. The difficulties of designing future coastlines in the face of climate change. Landscape Res. 39 (6), 613-630, http:// dx.doi.org/10.1080/01426397.2014.975108.

OECD, 2015. The Economic Consequences of Climate Change. OECD Publishing, Paris, http://dx.doi.org/10.1787/9789264235410-en.

Olsson, P., Gunderson, L.H., Carpenter, S.R., Ryan, P., Lebel, L., Folke, C., Holling, C.S. 2006. Shooting the rapids: navigating transitions to adaptive governance of social-ecological systems. Ecol. Soc. 11 (1), 18 http://hdl.handle.net/10535 3412.

Parry, M.L., Canziani, O.F., Palutikof, J.P., van der Linden, P.J., Hanson, C.E. (Eds.), 2007. Contribution of Working Group II to the Fourth Assessment Report of the Intergovernmental Panel on Climate Change. Cambridge University Press, Cambridge.

Pelling, M., High, C., 2005. Understanding adaptation: what can social capital offer assessments of adaptive capacity? Global Environ. Change 15 (4), 308-319, http://dx.doi.org/10.1016/j.gloenvcha.2005.02.001.

Pelling, M., O'Brien, K., Matyas, D., 2014. Adaptation and transformation. Clim. Change, 1-15, http://dx.doi.org/10.1007/s10584-014-1303-0.

Pelling, M., 2010. Adaptation to Climate Change: From Resilience to Transformation. London, Routledge.

Putnam, R., 2000. Bowling Alone: The Collapse and Revival of American Community. Simon \& Schuster, New York.

Schmidt, L., Guerra, J., 2010. Da Governança Global à Sustentabilidade Local -Portugal e o Brasil em Perspetiva Comparada. Revista de Ciências Sociais 41 (2), 106-124.

Schmidt, L., Gomes, C., Guerreiro, S., O'Riordan, T., 2014. Are we all on the same boat? The challenge of adaptation facing Portuguese coastal communities: risk perception, trust-building and genuine participation. Land Use Policy 38, 355-365, http://dx.doi.org/10.1016/j.landusepol.2013.11.008.

Sein, D., Cabos, W., Jacob, D., 2014. Future Climate Change RCP4. 5 and RCP8. 5 Scenarios Downscaling for the Northern Europe with the Focus on the North and Baltic Seas, 3. International Baltic Earth Secretariat Publications, pp. 59-60 10013/epic.45009.d001.

Smit, B., Wandel, J., 2006. Adaptation, adaptive capacity and vulnerability. Global Environ. Change 16 (3), 282-292, http://dx.doi.org/10.1016/j.gloenvcha.2006. 03.008.

Stewart, I.D., Oke, T.R., 2012. Local climate zones for urban temperature studies. Bull. Am. Meteorol. Soc. 93 (12), 1879-1900, http://dx.doi.org/10.1175/BAMSD-11-00019.1.

Truninger, M. Freire, D. 2014. Unpacking the Mediterranean diet: agriculture, food and health. In: Domingos, N., Sobral, J.M., West, H. (Eds.), Food Between the Country and the City: Ethnographies of a Changing Global Foodscape. Bloomsbury, London.

Waksberg, J., 1978. Sampling methods for random digit dialing. J. Am. Stat. Assoc. 73 (361), 40-46.

Wise, R.M., Fazey, I., Smith, M.S., Park, S.E., Eakin, H.C., Van Garderen, E.A., Campbell, B., 2014. Reconceptualising adaptation to climate change as part of pathways of change and response. Global Environ. Change 28, 325-336.

Wood, D., Stocker, L., 2009. Coastal adaptation to climate change: towards reflexive governance. Int. J. Sci. Soc. 1, 137-145. 